\title{
A Study on Factors Affecting Learning Persistence Intension of University Students
}

\author{
Young-mi MOON \\ Associate professor, \\ Department of Social Welfare, \\ Baekseok Arts University, South Korea \\ Email: youngmoon33 [AT] daum.net
}

\begin{abstract}
This study suggests practical measures to colleges and universities in plight of declining number of students. We collected and inquired into specific factors that affect learning persistence. The result of analysis on those factors affecting learning persistence proposes learning efficacy, academic major satisfaction, and school satisfaction as statistically significant ones.

The measures to maintain attending ratio and reduce dropouts rates based on the result above can be suggested as follows. First, the precondition is to select students with basic learning ability to follow major courses.

Second, to maintain learning, it is more important than any others that the enrolled students are given in each school customized approaches to majors that have stress on correlation with individuals' grades for satisfaction found in major courses and motivation to focus on learning by highlighting strong points of the majors.

Last, it will be helpful to carry out image-making or public promotion activities that may encourage pride in their schools. To add, expansion of welfare programs or amenities for students are considered to help increase students' will to keep learning.
\end{abstract}

Keywords---- learning persistence, learning self-efficacy

\section{INTRODUCTION}

Since 2018, the number of graduates entering the university is expected to exceed the number of high school graduates in Korea. While the entrance rate has been declining since 2014, the increasing number of colleges and universities will accelerate polarization in supplement of new students between colleges and universities. It will be a serious distress to those educational institutions because such trend will lead to shortfall of new students and higher dropout rate due to transfer to schools in the capital area. According to the National Statistical Office, the education age population of South Korea was 8,677 in 2010 and 7,940 in 2013, which will rapidly decrease to 7,164 in 2017, 6,805 in 2020, and 6,633 in 2030 (National Statistics Office, www.kostat.go.kr).

Owing to the present situation and reasons so far, colleges and universities have begun to pay attention to maintaining the number of current students as facing declining resource for new students. Although recruitment of new students has received more attention, retention of current students received relatively less attention and lower academic interest. Since 1970s, studies in the United States have begun to investigate the effect of the dropout rate on employment and university finance (Kim Jae-woong, 1991). Most of the initial studies considered personal attitude, capacity, and motivation as causes of dropouts. Domestic studies tried to suggest solutions for dropouts and learning persistence of undergraduate students since 2000s, but they were not considered as serious problems because dropouts were regarded as personal problems. Within such context, most of the domestic studies focused on personal factors and serious researches on undergraduate level are rarely found (Jeong, Jae-young. Sun, mi-suk, and Jeong Min-ji ,2015) .

Therefore, this study divided the factors that affect learning persistence into personal, school, and social aspects to verify whether school satisfaction, social support, major commitment, and academic self-efficacy of undergraduate students have significant effect on learning persistence.

\section{PRECEDENT RESEARCH}

Learning Persistence Intention

Academic persistence intention is learner's will to complete learning (Yorke, 2004), which refers the will to enroll the following term to complete learning and graduate from the undergraduate school to which the students currently belong (Shin,2003). Muiler (2008) explained that learning persistence is to continually join an educational program and complete a program or degree courses, and Kember (2005) to continue to enroll and learn education or degree courses provided by an institution. On the other hand, Jung, Geum-sook (2011) defined learning persistence intention as individual's continuation of learning for life in a large sense. Researches on learning persistence intention have mostly been conducted in e-learning context such as cyber universities or corporates (Jung, Young-Joo, Chung, Ae-kyung, Han, ari-lee, 2011). Even in traditional colleges and universities, however, emotional, social, learning, or institutional 
dissatisfaction of students led to dropouts. Robbins et al. (2004) carried out a meta-analysis on psycho-sociological factors, learning techniques, outcome and verified significant relationship between learning self-efficacy and learning persistence. Torres and Solberg (2001) proved that learning self-efficacy predicts persistence intention with Latin American undergraduate students as subjects. Choi, Mi-Na and Noh, Hye-Ran (2015), in a study on learning satisfaction and motive to register as variables to affect persistence of e-learning in undergraduate schools, stated that learning persistence intention for e-learning increases when learners consider that interaction with instructors and content of learning are sufficient, also when preparation for tests are easy, and good grades are achieved. In addition, Jung, YoungJoo, Chung, Ae-Kyung, Choi, Hye-Ri. (2012) mentioned that school support variables, school immersion, and studying immersion have significant roles for learning satisfaction and learning persistence intention.

. To summarize studies presented so far, many previous studies analyzed details of personal factors, and recent ones intermittently showed collection and analyses of various factors effective on learning persistence intention of students by adding social and school factors.

\section{RESEARCH}

The significance level of this study is $\mathrm{p}<0.05$ and SPSS ver21.0 was used to analyze coded data of the questionnaire.

Firstly, a frequency analysis calculated frequency and percentage for demographic factors of samples. Secondly, a descriptive statistical analysis calculated the average and standard deviation to analyze distribution of measurement variables. Thirdly, Cronbach's Alpha, which analyzes internal consistency, was used to verify confidence of measurement variables. Fourth, a correlation analysis was used to analyze the correlation between measurement variables. Fifth, an independent sample t-test and a variance analysis were conducted to analyze the difference of learning persistence intention according to personal factors of undergraduate students. Lastly, a multiple regression analysis analyzed the factors that affect learning persistence intention.

\subsection{Analysis on Demographic Factors of Samples}

\begin{tabular}{|c|c|c|c|}
\hline \multicolumn{2}{|c|}{ division } & frequency & percent \\
\hline \multirow{2}{*}{ Gender } & Male & 76 & 29.2 \\
\hline & Female & 184 & 70.8 \\
\hline \multirow{4}{*}{ School Year } & $1^{\text {st }}$ year & 141 & 54.2 \\
\hline & $2^{\text {nd }}$ year & 84 & 32.3 \\
\hline & $3^{\text {rd }}$ year & 15 & 5.8 \\
\hline & $4^{\text {th }}$ year & 20 & 7.7 \\
\hline \multirow{2}{*}{ Age } & $10-20$ years & 254 & 97.7 \\
\hline & 30 years or older & 6 & 2.3 \\
\hline \multirow{4}{*}{ Major } & $\begin{array}{l}\text { Humanities and Social } \\
\text { Sciences }\end{array}$ & 133 & 51.2 \\
\hline & Natural Sciences & 19 & 7.3 \\
\hline & Art and PE & 31 & 11.9 \\
\hline & Others & 77 & 29.6 \\
\hline \multirow{5}{*}{ Religion } & Christianity & 84 & 32.3 \\
\hline & Catholicism & 19 & 7.3 \\
\hline & Buddhism & 11 & 4.2 \\
\hline & Atheism & 139 & 53.5 \\
\hline & Others & 7 & 2.7 \\
\hline \multirow{4}{*}{ Commuting time } & Within 30 mins & 36 & 13.8 \\
\hline & Within 1 hours & 86 & 33.1 \\
\hline & Within 2 hours & 108 & 41.5 \\
\hline & More than 2 hours & 30 & 11.5 \\
\hline \multicolumn{2}{|c|}{ Total } & 260 & 100.0 \\
\hline
\end{tabular}


The result of demographic analysis on the samples shows that they consist of $70.8 \%$ of females and $29.2 \%$ of males, $54.2 \%$ of $1^{\text {st }}$ year students followed by $2^{\text {nd }}, 4^{\text {th }}$, and $3^{\text {rd }}$ year ones, $97.7 \%$ of $10-20$ years of age range and $2.3 \%$ of those who are older than 30 years of age. Humanities and social science majors account for the highest by $51.2 \%$, which is followed by others, art and physical education, and natural sciences, atheism by $53.5 \%$ followed by Christianity, Catholicism, Buddhism, and others, and within 2 hours of commuting by $41.5 \%$ followed by within 1 hour, within 30 minutes, and more than 2 hours.

\subsection{Descriptive statistical analysis and Confidence Verification for Measurement Variables}

\begin{tabular}{c|c|c|c|c}
\hline & $\mathrm{N}$ & Average & $\begin{array}{c}\text { Standard } \\
\text { Deviation }\end{array}$ & $\begin{array}{c}\text { Cronbach's' } \\
\text { Alpha }\end{array}$ \\
\hline Social Support & 260 & 3.65 & .68 & .769 \\
Learning Efficacy & 260 & 3.43 & .61 & .869 \\
Major Satisfaction & 260 & 3.66 & .73 & .871 \\
School Satisfaction & 260 & 3.36 & .75 & .913 \\
Academic Persistence Intention & 260 & 3.75 & .59 & .840 \\
\hline
\end{tabular}

The result of descriptive statistical analysis on measurement variables reveals that learning persistence intention has the highest of 3.75, which is followed by major satisfaction, social support, learning efficacy, and school satisfaction. And, the result of confidence verification was high with 0.769-0.913 for Cronbach's Alpha.

\subsection{Correlation Analysis on Measurement Variables}

\begin{tabular}{|c|c|c|c|c|c|}
\hline & $\begin{array}{c}\text { Social } \\
\text { Support }\end{array}$ & $\begin{array}{l}\text { Learning } \\
\text { Efficacy }\end{array}$ & $\begin{array}{c}\text { Major } \\
\text { Satisfaction }\end{array}$ & $\begin{array}{c}\text { School } \\
\text { Satisfaction }\end{array}$ & $\begin{array}{l}\text { Academic } \\
\text { Persistence } \\
\text { Intention }\end{array}$ \\
\hline $\begin{array}{c}\text { Social } \\
\text { Support }\end{array}$ & 1 & & & & \\
\hline $\begin{array}{l}\text { Learning } \\
\text { Efficacy }\end{array}$ & $.411 * * *$ & 1 & & & \\
\hline $\begin{array}{c}\text { Major } \\
\text { Satisfaction }\end{array}$ & $.293 * * *$ & $.594 * * *$ & 1 & & \\
\hline $\begin{array}{c}\text { School } \\
\text { Satisfaction }\end{array}$ & $.165^{* * * *}$ & $.435^{* * *} *$ & $.613 * * *$ & 1 & \\
\hline $\begin{array}{l}\text { Academic } \\
\text { Persistence } \\
\text { Intention }\end{array}$ & $.272 * * *$ & $.488 * * *$ & $.581 * * *$ & $.695 * * *$ & 1 \\
\hline
\end{tabular}

The result of analysis on correlation between measurement variables showed positive correlations in all of social support, learning efficacy, major satisfaction, school satisfaction, and learning persistence intention (0.165-0.695). In other words, they had the same relations between variables set by the researcher. 
3.4.Analysis on the Difference of Academic Persistence Intention according to Personal Factors of Undergraduate Students

\begin{tabular}{|c|c|c|c|c|c|c|}
\hline & & $\mathrm{N}$ & Average & $\begin{array}{c}\text { Standard } \\
\text { Deviation }\end{array}$ & $\mathrm{t}$ & $\mathrm{p}$ \\
\hline \multirow{2}{*}{ Gender } & Male & 76 & 3.70 & .64 & \multirow{3}{*}{-.788} & \multirow{3}{*}{.432} \\
\hline & Female & 184 & 3.76 & .58 & & \\
\hline \multicolumn{2}{|c|}{ Total } & 260 & 3.73 & .61 & & \\
\hline \multirow{4}{*}{ School Year } & $1^{\text {st }}$ year & 141 & 3.77 & .59 & \multirow{5}{*}{.312} & \multirow{5}{*}{.817} \\
\hline & $2^{\text {nd }}$ year & 84 & 3.74 & .61 & & \\
\hline & $3^{\text {rd }}$ year & 15 & 3.73 & .70 & & \\
\hline & $4^{\text {th }}$ year & 20 & 3.64 & .43 & & \\
\hline \multicolumn{2}{|c|}{ Total } & 260 & 3.75 & .59 & & \\
\hline \multirow{4}{*}{$\begin{array}{l}\text { Commuting } \\
\text { Time }\end{array}$} & $\begin{array}{c}\text { Within } 30 \\
\text { mins }\end{array}$ & 36 & 3.65 & .65 & \multirow{5}{*}{.487} & \multirow{5}{*}{.692} \\
\hline & $\begin{array}{c}\text { Within } 1 \\
\text { hours }\end{array}$ & 86 & 3.74 & .62 & & \\
\hline & $\begin{array}{c}\text { Within } 2 \\
\text { hours }\end{array}$ & 108 & 3.77 & .55 & & \\
\hline & $\begin{array}{c}\text { More than } \\
2 \text { hours }\end{array}$ & 30 & 3.81 & .60 & & \\
\hline \multicolumn{2}{|c|}{ Total } & 260 & 3.75 & .59 & & \\
\hline
\end{tabular}

The result of an analysis on the difference of learning persistence Intention according to genders did not show a statistically significant difference $(t=-0.788, p>0.05)$. Therefore, it is found that gender does not make any difference in learning persistence intention.

The result of an analysis on the difference of learning persistence intention according to school years did not show a statistically significant difference $(\mathrm{F}=0.312, \mathrm{p}>0.05)$. Therefore, it is found that school year does not make any difference in learning persistence intention.

The result of an analysis on the difference of learning persistence intention according to commuting time did not show a statistically significant difference $(\mathrm{F}=0.487, \mathrm{p}>0.05)$. Therefore, it is found that commuting time does not make any difference in learning persistence intention.

\subsection{Analysis on Factors Effective on Academic Persistence Intention}

\begin{tabular}{|c|c|c|c|c|c|c|c|c|}
\hline \multirow{2}{*}{$\begin{array}{l}\text { Dependent } \\
\text { Variables }\end{array}$} & \multirow{2}{*}{$\begin{array}{l}\text { Independent } \\
\text { Variables }\end{array}$} & \multicolumn{2}{|c|}{$\begin{array}{l}\text { Unstandardized } \\
\text { Coefficients }\end{array}$} & \multirow{2}{*}{$\begin{array}{c}\text { Standardized } \\
\text { Coefficients }\end{array}$} & \multirow{2}{*}{$\mathrm{t}$} & \multirow{2}{*}{$\mathrm{p}$} & \multicolumn{2}{|c|}{$\begin{array}{l}\text { Collinearity } \\
\text { Statistics }\end{array}$} \\
\hline & & B & $\begin{array}{l}\text { Standard } \\
\text { Error }\end{array}$ & & & & Tolerance & VIF \\
\hline \multirow{5}{*}{$\begin{array}{l}\text { Academic } \\
\text { Persistence } \\
\text { Intention }\end{array}$} & (Constant) & 1.172 & .178 & & 6.576 & .000 & & \\
\hline & $\begin{array}{l}\text { Social } \\
\text { Support }\end{array}$ & .076 & .041 & .086 & 1.852 & .065 & .825 & $\begin{array}{c}1.21 \\
3\end{array}$ \\
\hline & $\begin{array}{l}\text { Learning } \\
\text { Efficacy }\end{array}$ & .128 & .055 & .131 & $2.353^{*}$ & .019 & .576 & $\begin{array}{c}1.73 \\
6\end{array}$ \\
\hline & $\begin{array}{c}\text { Major } \\
\text { Satisfaction }\end{array}$ & .123 & .049 & .152 & $2.518^{*}$ & .012 & .488 & $\begin{array}{c}2.04 \\
7\end{array}$ \\
\hline & $\begin{array}{c}\text { School } \\
\text { Satisfaction }\end{array}$ & .419 & .043 & .531 & $9.845^{* * *}$ & .000 & .615 & $\begin{array}{c}1.62 \\
7\end{array}$ \\
\hline & & & Square & $45, \mathrm{~F}=76.262$ & & & & \\
\hline
\end{tabular}

$* \mathrm{p}<.05, * * * \mathrm{p}<.001$ 
The result of an analysis on the factors that affect learning persistence intention presents 0.545 for $\mathrm{R}$ Square value with $54.5 \%$ for explanation power of the regression model, $\mathrm{F}=76.262$ shows statistical significance of the regression model. Multicollinearity of independent variables were not found with 0.1 or higher tolerance limit and 10.0 or lower VIF value. The result of an analysis of the factors that affect learning persistence intention showed that learning efficacy ( $\mathrm{t}=2.353$, $\mathrm{p}<0.05)$, major satisfaction ( $\mathrm{t}=2.518, \mathrm{p}<0.05)$, school satisfaction $(\mathrm{t}=9.845, \mathrm{p}<0.001)$ have positive effect on learning persistence intention. However, social support does not affect learning persistence intention.

\section{CONCLUSION AND IMPLICATION}

In the result of this study, the difference in learning persistence intention due to gender, school year, and commuting time did not show statistically significant differences. In other words, gender, school year, and commuting time do not create difference in learning persistence intention.

The result of an analysis on the factors that affect learning persistence intention shows statistical significance. In other words, learning efficacy $(\mathrm{t}=2.353, \mathrm{p}<0.05)$, major satisfaction $(\mathrm{t}=2.518, \mathrm{p}<0.05)$, school satisfaction $(\mathrm{t}=9.845, \mathrm{p}<0.001)$ have positive effect on learning persistence intention. However, social support does not affect learning persistence intention.

The result corresponds with the suggestions of previous studies in some parts but there are new implications as well. Many colleges and universities put various efforts to create good senior-junior relationship in early period of a new school year, but the participation rate keeps declining. It reflects the contemporary trend in that current students prefer temporary relationship where students gather and scatter by their interests or horizontal relationship in social media instead of subordinate-and-superior or formal relationship between seniors and juniors. In addition, as undergraduate students start independence from parents, parental support or help does not have substantial effect on school life.

The measures to maintain attending ratio and reduce dropouts based on the result above can be suggested as follows. First, the precondition is to select students with basic learning ability to follow major courses.

Second, to maintain learning, it is more important than any others that the enrolled students are given in each school customized approaches to majors that have stress on correlation with individuals' grades for satisfaction found in major courses and motivation to focus on learning by highlighting strong points of the majors.

Last, it will be helpful to carry out image-making or public promotion activities that may encourage pride in their schools. To add, expansion of welfare programs or amenities for students are considered to help increase students' will to keep learning.

\section{REFERENCES}

- Kember, D.(2005). Open learning courses for adults. A model of student progress. Englewood Cliffs, NJ:Educational Technology Publications.

- Müller, T.(2008), "Persistence of women in online degree completion programs" 9 (9)

- Robbins, S. B.(2004), "Do psychosocial and study skill factors predict college outcomes? A meta-analysis" 130 (130)

- Torres, J. B., \& Solberg, V. S.(2001). Role of Self-Efficacy, Stress, Social Integration, and Family Support in LatinoCollege Student Persistence and Health. Journal of Vocational Behavior, 59(1)

- Yorke, M.(2004). Retention, persistence and success in on-campus higher education, and their enhancement in open and distance learning. Ope

- Choi, Mi-Na and Noh, Hye-Ran. (2015). "A Study on the Combined Development of College e-Learning Based on MOOCs". "Digital fusion research". 13 (7).

- Jung Geum Sook. (2011). "The impact of corporate e-learning on satisfaction and persistent intentions The structural relationship of factors. Ewha Womans University Thesis.

- Shin N. (2003). "Transactional presence as a critical predictor of success in distance learning ". Distance Education. 24 (1),

- Kim Jae-woong. (1991), "Dropping Out of American University Students: Relative Importance of Individuals, Social Structure, and Universities"

- $\quad$ National Statistical Office, www.kostat.go.kr/ 